\title{
Survey of aflatoxins in tomato products
}

\author{
Aflatoxinas em produtos de tomate
}

\section{Lilian Regina Barros MARIUTTI ${ }^{1 *}$, Lucia Maria VALENTE SOARES ${ }^{1}$}

\begin{abstract}
Tomatoes are highly susceptible to fungi contamination in the field, during transportation, processing, and storage. Aspergillus flavus and Aspergillus parasiticus have been isolated from tomatoes and tomato products, and both fungi species can produce aflatoxin, mycotoxin with hepatotoxic, carcinogenic, teratogenic, and mutagenic effects on all animal species tested so far. In order to verify a possible aflatoxin contamination of tomato products commercialized in Brazil, 63 samples of tomato products (pulp, paste, purée, ketchup, dehydrated tomatoes, and dried tomatoes preserved in oil) produced in 5 Brazilian states and 1 imported sample (ketchup), totalizing 29 brands, were analyzed by thin layer chromatography. The analytical method showed an average recovery of $86 \%$ for all aflatoxins at two spiking levels. The limits of detection for the aflatoxins $B_{1}, B_{2}, G_{1}$, and $G_{2}$ varied with the type of the product ranging from 2 to $7 \mu \mathrm{g} / \mathrm{kg}$. Aflatoxins were not detected in any evaluated sample indicating that they did not pose a risk to human health since there was no invasion of raw materials by toxigenic fungi or no conditions for toxin production.

Keywords: mycotoxins; aflatoxins; tomato products.
\end{abstract}

\section{Resumo}

Os tomates são frutos altamente susceptíveis à contaminação fúngica tanto no campo como durante o transporte, processamento e armazenamento. Aspergillus flavus e Aspergillus parasiticus têm sido isolados em tomate e em produtos de tomate e ambas as espécies são produtoras de aflatoxinas, potentes micotoxinas que apresentam efeitos hepatotóxicos, carcinogênicos, teratogênicos e mutagênicos para todas as espécies animais testadas até o momento. Para verificar a possível contaminação por estas micotoxinas em produtos de tomate comercializados no Brasil, amostras de 63 produtos de tomate (polpa, pasta, purê, catchup, tomate desidratado e tomate seco conservado em óleo) provenientes de 5 Estados brasileiros e uma do exterior (catchup), compreendendo a 29 marcas, foram analisadas por cromatografia em camada delgada. A avaliação do método para determinação das aflatoxinas em produtos de tomate resultou em uma recuperação média de $86 \%$, para as quatro aflatoxinas, em dois níveis de adição. Os limites de detecção para as aflatoxinas $\mathrm{B}_{1}, \mathrm{~B}_{2}, \mathrm{G}_{1}$ e $\mathrm{G}_{2}$ variaram de 2 a $7 \mu \mathrm{g} / \mathrm{kg}$, dependendo do tipo de produto. As aflatoxinas não foram detectadas em nenhuma das amostras avaliadas, indicando que não apresentavam risco à saúde humana, seja por ausência de invasão por fungos toxigênicos ou por falta de condições para produção das toxinas.

Palavras-chave: micotoxinas; produtos de tomate; aflatoxinas.

\section{Introduction}

Tomatoes are soft skin fruits highly susceptible to fungi contamination, mainly through injured skin or damaged tissues (AYRES; KRAFT; PIERCE, 1964; PEARSON; HALL, 1975). Strains from several fungi species are known to produce toxins on tomatoes during field production or storage. In the U.S.A., the main fungi genera found in tomatoes were Alternaria, Aspergillus, Botrytis, Cladosporium, Colletotrichum, Fusarium, Geotrichum, Mucor, Penicillium, Phytophthora, Rhizophus, and Stemphylium (AYRES; KRAFT; PIERCE, 1964; HARWIG et al., 1979; MISLIVEC et al., 1987). Tenuazonic acid, an Alternaria toxin, was detected in tomato products in Canada and in the U.S.A. (SCOTT; KANHERE, 1980; STACK et al., 1985). Low levels of tenuazonic acid were also found in national tomato products, as well as ciclopiazonic acid, a toxin produced by Penicillium and Aspergillus genera (MOTTA; SOARES, 2001). On the other hand, the analysis of national tomato products for verruculogen, produced by Penicillium, and patulin, produced by Penicillium, Aspergillus and Byssochlamys, showed negative results (KAWASHIMA; SOARES; MASSAGUER, 2002). Aflatoxin, an Aspergillus toxin, was detected in rotten tomatoes commercialized in Nigeria (MUHAMMAD; SHEHU; AMUSA, 2004).

At least 10 Aspergillus species can be recognized as able to biosynthesize aflatoxins (PETERSON et al., 2001; ITO et al., 2001; FRISVAD; SKOUBOE; SAMSON, 2005; KENJO et al., 2007; EHRLICH et al., 2007), and among these species Aspergillus flavus and Aspergillus parasiticus draw special interest from researchers because they are the most common fungi species known to be able to produce aflatoxins (GOURAMA; BULLERMAN, 1995). Aflatoxins $B_{1}, B_{2}, G_{1}$ and $G_{2}$

Recebido para publicação em 4/11/2007

Aceito para publicação em 9/3/2008 (002989)

${ }^{1}$ Departamento de Ciência de Alimentos, Faculdade de Engenharia de Alimentos, Universidade Estadual de Campinas - UNICAMP, CP 6121, CEP 13081-970,

Campinas, SP, Brasil, E-mail: lilianmariutti@gmail.com

${ }^{*}$ A quem a correspondência deve ser enviada 
are thermostable compounds (MARASAS; NELSON, 1987) and can cause carcinogenic, teratogenic, and mutagenic damages in animals (BUSBY; WOGAN, 1981). They occur worldwide on a large variety of foods and feeds.

Reports of tomatoes contaminated with Aspergillus spp. (MISLIVEC et al., 1987; OLADIRAN; IWU, 1993; OBETA; UGWUANYI, 1995), and the ability of some Aspergillus strains to produce aflatoxins in tomato products (LUCISANO; CAMPANINI; CASOLARI, 1972; MUTTI; DELLAPINA; SPOTTI, 1992; MUHAMMAD; SHEHU; AMUSA, 2004) indicate the need to verify the possible contamination of tomato products with aflatoxins.

In Brazil, the tomato production reached 3.1 million ton in 2005, and the state of São Paulo is considered the second major tomato producer in the country (672 thousand ton) (MAPA, 2007). One third of the national tomato production is destined to the manufacture of sauces, ketchup, paste, pulp, and juices. Due to the large use of these products by the population, all health aspects, including the possible presence of mycotoxins, are of great interest as a public health issue.

The aims of the present work were 1) to optimize a method for aflatoxin determination in tomato products using thin layer chromatography due to its low cost and simplicity of use; and 2) to verify the incidence of aflatoxins in tomato products commercialized in São Paulo, Brazil.

\section{Materials and methods}

\subsection{Sampling}

A total of 64 tomato products (Table 1) were purchased in supermarkets between March and November 2001 in the cities of Campinas and São Paulo, São Paulo State, Brazil. The samples were maintained in at their original container (cans, glass jars, and cartons) and at the original storage conditions (room temperature) until analysis. The samples were homogenized manually before taking the portion for analysis. All the analyses were performed before the expiration date.

Table 1. Samples analysed for aflatoxins.

\begin{tabular}{lccc}
\hline \multicolumn{1}{c}{ Product } & Samples $^{\mathrm{a}}$ & Brand $^{\mathrm{b}}$ & Origin $^{\mathrm{c}}$ \\
\hline Hot ketchup & 6 & 6 & SC, RS, SP, GO \\
Hot ketchup & 1 & 1 & USA \\
Traditional ketchup & 9 & 9 & SC, SP, GO \\
Tomato paste & 15 & 12 & MG, SP, GO \\
Tomato pulp & 14 & 10 & SP, RS, GO \\
Tomato purée & 7 & 4 & SP, GO \\
Dehydrated tomato & 4 & 3 & SP \\
Dried tomato preserved in oil & 8 & 8 & SP
\end{tabular}

${ }^{a}$ Number of samples. ${ }^{b}$ Number of different brands. 'SC, Santa Catarina State, Brazil; RS, Rio Grande do Sul State, Brazil; SP, São Paulo State, Brazil; GO, Goiás State, Brazil; USA, United States of America; MG, Minas Gerais State, Brazil

\subsection{Determination of aflatoxins $B_{1}, B_{2}, G_{1}$, and $G_{2}$ in tomato products}

The aflatoxins $B_{1}, B_{2}, G_{1}$, and $G_{2}$ were determined according to the method described by Soares and Rodriguez-Amaya (1989) with modifications that were introduced due to the high moisture content of the tomato products. Fifty grams of the samples were extracted with $270 \mathrm{ml}$ methanol and $1.2 \mathrm{~g} \mathrm{KCl}$ in a domestic blender for 5 minutes at low speed. The extract was filtered into a graduated cylinder through a qualitative filter paper and the filter residue was washed using $50 \mathrm{ml}$ methanol. For the samples of dehydrated tomatoes and dried tomatoes preserved in oil, $30 \mathrm{ml}$ aqueous $4 \% \mathrm{KCl}$ solution was used instead of $1.2 \mathrm{~g} \mathrm{KCl}$ and the filter residue was not washed with methanol.

The cleaning up was performed with an aliquot of $200 \mathrm{ml}$ of the filtrate $(150 \mathrm{~mL}$ for the dehydrated tomatoes and dried tomatoes preserved in oil) by the addition of $150 \mathrm{ml} 30 \%\left(\mathrm{NH}_{4}\right)_{2} \mathrm{SO}_{4}$ solution and $50 \mathrm{~cm}^{3}$ of Hyflo Super-Cel (Lompoc, U.S.A). After mixing with a glass stirring rod, the mixture was filtered. $150 \mathrm{ml}$ were transferred to a separatory funnel and $150 \mathrm{ml}$ of water were added. Two partitions with $10 \mathrm{ml}$ chloroform were performed and $5 \mathrm{ml}$ of each chloroform layer were combined and evaporated to dryness on water bath $\left(60^{\circ} \mathrm{C}\right)$ under nitrogen stream. The residue was dissolved with $200 \mu \mathrm{l}$ benzene and sonicated for 30 seconds. The aflatoxins $B_{1}, B_{2}, G_{1}$, and $G_{2}$ standards (Sigma Chemical Co., U.S.A.) and the sample extracts were spotted conveniently on a TLC silica plate ( $0.25 \mathrm{~mm}$, Merck, Germany). The plate was developed in a non-saturated chromatographic chamber (Desaga, Germany) with chloroform-acetone $(9+1$, v/v). The spots intensities were visually compared under ultraviolet light at $366 \mathrm{~nm}$ (Mineralight, UVP Inc., U.S.A.). All solvents and reagents were of analytical grade. The aflatoxin standards were prepared according to the method 970.44 of the Official Methods of Analysis, AOAC International (1998).

\subsection{Analytical quality control}

The recovery tests were conducted in duplicate and two addition aflatoxin levels were evaluated. Non-contamined tomato product samples were spiked with $6.8 \mu \mathrm{g} / \mathrm{kg}$ of aflatoxin $\mathrm{B}_{1}$; $5.7 \mu \mathrm{g} / \mathrm{kg}$ of aflatoxin $B_{2} ; 8.1 \mu \mathrm{g} / \mathrm{kg}$ of aflatoxin $\mathrm{G}_{1}$, and $5.9 \mu \mathrm{g} / \mathrm{kg}$ of aflatoxin $\mathrm{G}_{2}$ (addition level I); and with $16.9 \mu \mathrm{g} / \mathrm{kg}$ of aflatoxin $B_{1}$; $14.3 \mu \mathrm{g} / \mathrm{kg}$ of aflatoxin $B_{2} ; 20.3 \mu \mathrm{g} / \mathrm{kg}$ of aflatoxin $G_{1}$, and $14.8 \mu \mathrm{g} / \mathrm{kg}$ of aflatoxin $\mathrm{G}_{2}$ (addition level II). The samples were considered not contaminated since no aflatoxin was detected when analysed under the conditions described previously in section 2.2.

The detection limits for the modified method were established for each kind of tomato product analyzed. On a TLC plate, $10 \mu \mathrm{l}$ of sample extract were spotted and over these spots different aliquots of aflatoxins $B_{1}, B_{2}, G_{1}$, and $G_{2}$ standards were spotted in order to achieve sample concentrations ranging from 2 to $20 \mu \mathrm{g} / \mathrm{kg}$. The limit of detection was considered the last visible concentration of the aflatoxin fluorescence under UV light after the development with chloroform-acetone $(9+1)$. 
Table 2. Recovery (\%) of aflatoxins $B_{1}, B_{2}, G_{1}$, and $G_{2}$.

\begin{tabular}{|c|c|c|c|c|c|c|c|c|c|c|}
\hline \multirow[t]{2}{*}{ Tomato Product } & \multicolumn{5}{|c|}{ Addition level I $^{\mathrm{a}}$} & \multicolumn{5}{|c|}{ Addition level $\mathrm{II}^{\mathrm{b}}$} \\
\hline & $\mathrm{B}_{1}$ & $\mathrm{~B}_{2}$ & $\mathrm{G}_{1}$ & $\mathrm{G}_{2}$ & Total & $\mathrm{B}_{1}$ & $\mathrm{~B}_{2}$ & $\mathrm{G}_{1}$ & $\mathrm{G}_{2}$ & Total \\
\hline Ketchup & $84 \pm 0$ & $84 \pm 0$ & $84 \pm 0$ & $84 \pm 0$ & $84 \pm 0$ & $89 \pm 6$ & $89 \pm 6$ & $89 \pm 6$ & $89 \pm 6$ & $89 \pm 6$ \\
\hline Pulp & $83 \pm 5$ & $83 \pm 5$ & $83 \pm 5$ & $83 \pm 5$ & $83 \pm 5$ & $96 \pm 2$ & $96 \pm 2$ & $96 \pm 2$ & $96 \pm 2$ & $96 \pm 2$ \\
\hline Paste & $76 \pm 1$ & $76 \pm 1$ & $76 \pm 1$ & $76 \pm 1$ & $76 \pm 1$ & $88 \pm 5$ & $88 \pm 5$ & $88 \pm 5$ & $88 \pm 5$ & $88 \pm 5$ \\
\hline Purée & $88 \pm 8$ & $88 \pm 8$ & $88 \pm 8$ & $88 \pm 8$ & $88 \pm 8$ & $95 \pm 5$ & $95 \pm 5$ & $94 \pm 4$ & $95 \pm 5$ & $95 \pm 4$ \\
\hline Dehydrated & $81 \pm 3$ & $81 \pm 3$ & $81 \pm 3$ & $81 \pm 3$ & $81 \pm 3$ & $91 \pm 8$ & $91 \pm 8$ & $91 \pm 8$ & $91 \pm 8$ & $91 \pm 8$ \\
\hline
\end{tabular}

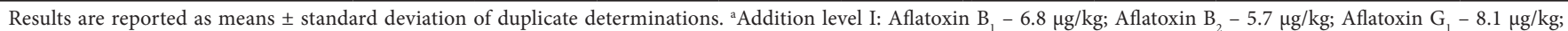
Aflatoxin $\mathrm{G}_{2}-5.9 \mu \mathrm{g} / \mathrm{kg}$; Total aflatoxin $-26.5 \mu \mathrm{g} / \mathrm{kg}$. ${ }^{\mathrm{b}}$ Addition level II: Aflatoxin $\mathrm{B}_{1}-16.9 \mu \mathrm{g} / \mathrm{kg}$; Aflatoxin $\mathrm{B}_{2}-14.3 \mu \mathrm{g} / \mathrm{kg} ; \mathrm{Aflatoxin} \mathrm{G}_{1}-20.3 \mu \mathrm{g} / \mathrm{kg} ; \mathrm{Aflatoxin} \mathrm{G}_{2}-14.8 \mu \mathrm{g} / \mathrm{kg}$; Total aflatoxin $-66.3 \mu \mathrm{g} / \mathrm{kg}$.

\section{Results and discussion}

The method for the determination of aflatoxins $B_{1}, B_{2}, G_{1}$, and $G_{2}$ in cereals and beans developed by Soares and RodriguezAmaya (1989) was optimized for tomato products. The evaluation of the method resulted in an average recovery of $86 \%$ for the two levels of addition of standards for all aflatoxins tested (Table 2). The detection limit of each aflatoxin (Table 3 ) ranged from 2 to $7 \mu \mathrm{g} / \mathrm{kg}$ and from 8 to $23 \mu \mathrm{g} / \mathrm{kg}$ for total aflatoxins depending on the tomato product. None of the studies found in the literature on aflatoxin determination in tomato products were concerned about the optimization of the method nor did they present results for recovery tests. The detection limits for TLC analysis were lower than the values found in the present study, ranging from 1 to $10 \mu \mathrm{g} / \mathrm{kg}$ (GELOSA, 1983; MUTTI; DELLAPINA; SPOTTI, 1992). Moreover, it is important to note that in the cited studies there was no description of the method used for the determination of the detection limits while here they were determined for each product individually according to the method described in the section 2.3.

No aflatoxins were detected in any of the 64 analysed samples of the tomato products, considering the detection limits of the applied method. During the period between 1979 and 1982, the Public Health Laboratory in Milan, Italy, analyzed 14 samples of tomato paste and 14 samples of canned tomatoes and found no aflatoxins (detection limit: 5-10 $\mu \mathrm{g} / \mathrm{kg}$ ). Furthermore, these same samples were found to be free from patulin and ochratoxin (GELOSA, 1983). In another study also carried out in Italy, no aflatoxins were detected in 70 tomato products commercially avaiable: 40 of juices; 20 of pastes with $28 \%$ solids; and 10 of pastes with $36 \%$ solids (detection limit:1 $\mu \mathrm{g} / \mathrm{kg}$ ) (MUTTI; DELLAPINA; SPOTTI, 1992). On the other hand, on a survey of aflatoxin contamination between 2001 and 2002 in Nigeria, rotten tomatoes from 5 local markets were positive (detection limit not declared) for aflatoxin contamination even after autoclave treatment at $121{ }^{\circ} \mathrm{C}$ for 15 min (MUHAMMAD; SHEHU; AMUSA, 2004).

The presence of a toxigenic fungus in a foodstuff is not the only factor responsible for the toxin production since fungal growth and aflatoxin production are the consequence of interactions among the fungus, the host, and the environment. Other factors like the extent of the infection and proper
Table 3. Detection limits $(\mu \mathrm{g} / \mathrm{kg})$.

\begin{tabular}{lccccc}
\hline \multirow{1}{*}{ Tomato Product } & \multicolumn{5}{c}{ Aflatoxin } \\
\cline { 2 - 6 } & $\mathrm{B}_{1}$ & $\mathrm{~B}_{2}$ & $\mathrm{G}_{1}$ & $\mathrm{G}_{2}$ & Total \\
\hline Dehydrated & 6 & 5 & 7 & 5 & 23 \\
Dried and preserved in oil & 3 & 2 & 3 & 2 & 10 \\
Ketchup & 2 & 2 & 2 & 2 & 8 \\
Paste & 2 & 2 & 2 & 2 & 8 \\
Purée & 2 & 2 & 2 & 2 & 8 \\
Pulp & 2 & 2 & 2 & 2 & 8 \\
\hline
\end{tabular}

conditions for toxin production such as temperature, water content, medium composition, and the absence of antagonistic microorganisms are also important aspects that lead to detectable amounts of toxin although the precise factors that initiates toxin formation has not been well understood yet (NORTHOLT; VANEGMOND; PAULSCH, 1977; TRUCKSESS; STOLOFF; MISLIVEC, 1988; KHEIRALLA; HASSANIN; AMRA, 1992; PITT; MISCAMBLE, 1995; RAMAKRISHNA; LACEY; SMITH, 1996; GOURAMA, 1997). The fungus infeccion can be avoided in the field by the maintainance of the good agricultural practices. Therefore, the fruit selection and storage under proper conditions in the pre-processing stages are crucial in order to guarantee a final product free from toxins. Another important aspect of the mycotoxin production in foodstuff is the presence or absence of compounds that can inhibit the toxin synthesis. These compounds should be present at sufficient concentration to be able to be partial or completely effective. Tomatoes contain polyphenols (MARTÍNEZ-VALVERDE et al., 2002), which might be able to suppress the synthesis of such toxins although the adequate inhibitory concentration of these compounds remain undetermined (MALLOZZI et al., 1996; HUA; GROSJEAN; BAKER, 1999).

\section{Conclusions}

A method for aflatoxins determination in tomato products by thin layer chromatograph was optimized and an intralaboratory evaluation was carried out. Aflatoxins were not detected in any of the samples analyzed indicating that they did not pose risk to human health as far as the presence of aflatoxins is concerned. 


\section{References}

ASSOCIATION OF OFFICIAL ANALYTICAL CHEMISTS - AOAC. Official Methods of Analysis. Method 970.44. 16 ed. Gaithersburg, EUA, 1998

AYRES, J. C.; KRAFT, A. A.; PIERCE, L. C. Delaying spoilage of tomatoes. Food Technology, v. 18, n. 8, p. 100-103, 1964.

BRASIL. Ministério da Agricultura, Pecuária e Abastecimento. A agricultura brasileira em números. In: Estatística - Anuário 2005. Disponível em: <http://www.agricultura.gov.br/portal/ page?_pageid=33,2789141\&_dad=portal\&_schema=PORTAL $>$ : Acesso em: 6 de Outubro de 2007.

BUSBY Jr, W. F.; WOGAN, G. N. Aflatoxins. In: SHANK, R. C. (Ed.). Mycotoxins and N-nitroso compounds: Environmental risks. E.U.A: CRC Press, 1981. p. 3-28.

EHRLICH, K. C. et al. Aflatoxin-producing Aspergillus species from Thailand. International Journal of Food Microbiology, v. 114, n. 2, p. 153-159, 2007.

FRISVAD, J. C.; SKOUBOE, P.; SAMSON, R. A. Taxonomic comparison of three different groups of aflatoxin producers and a new efficient producer of aflatoxin B-1, sterigmatocystin and 3-O-methylsterigmatocystin, Aspergillus rambellii sp nov. Systematic and Applied Microbiology, v. 28, n. 5, p. 442-453, 2005.

GELOSA, L. La ricerca delle mico'tossine in un laboratorio di sanità pubblica. Industrie Alimentari, v. 22, n. 3, p. 175-178, 1983.

GOURAMA, H.; BULLERMAN, L. B. Aspergillus flavus and Aspergillus parasiticus: Aflatoxigenic fungi of concern in foods and feeds: A review. Journal of Food Protection, v. 58, n. 12, p. 1395-1404, 1995.

GOURAMA, H. Inhibition of growth and mycotoxin production of Penicillium by Lactobacillus species. LWT - Food Science and Technology, v. 3, v. 3, p. 279-283, 1997.

HARWIG, J. et al. Toxins of molds from decaying tomato fruit. Applied and Environmental Microbiology, v. 38, n. 2, p. 267-274, 1979.

HUA, S. S. T.; GROSJEAN, O. K.; BAKER, J. L. Inhibition of aflatoxin biosynthesis by phenolic compounds. Letters in Applied Microbiology, v. 29 , n. 5, p. 289-291, 1999.

ITO, Y. et al. Aspergillus pseudotamarii, a new aflatoxin producing species in Aspergillus section Flavi. Mycological Research, v. 105, n. 2, p. 233-239, 2001.

KAWASHIMA, L. M.; SOARES, L. M. V.; MASSAGUER, P. R. The development of an analytical method for two mycotoxins, patulin and verruculogen, and survey of their presence in commercial tomato pulp. Brazilian Journal of Microbiology, v. 33, n. 3, p. 269-273, 2002.

KENJO, T. et al. Fungal population and distribution of aflatoxigenic fungi in commercial almond powder products. Journal of the Food Hygienics Society of Japan, v. 48, n. 4, p. 90-96, 2007.

KHEIRALLA, Z. H.; HASSANIN, N. I.; AMRA, H. Effect of incubationtime, temperature and substrate on growth and aflatoxin production. International Biodeterioration and Biodegradation, v. 30, n. 1, p. 17-27, 1992

LUCISANO, A.; CAMPANINI, M.; CASOLARI, A. Contributo allo studio ambientali che condizionano la produzione di aflatossine negli alimenti. Industria Conserve, v. 47, n. 1, p. 27-31, 1972.

MALLOZZI, M. A. B. et al. Effect of flavonoids on Aspergillus flavus growth and aflatoxin production. Revista de Microbiologia, v. 27, n. 2, p. 161-165, 1996

MARASAS, W. F. O.; NELSON, P. E. Mycotoxicology. 1 ed. E.U.A.: The Pennsylvania State University Press, 1987.
MARTÍNEZ-VALVERDE, I. et al. Phenolic compounds, lycopene and antioxidant activity in commercial varieties of tomato (Lycopersicum esculentum). Journal of the Science of Food Agriculture, v. 82, n. 4 , p. 323-330, 2002.

MISLIVEC, P. B. et al. Molds and tenuazonic acid in fresh tomatoes used for catsup production. Journal of Food Protection, v. 50, n. 1, p. 38-41, 1987.

MOTTA, S.; SOARES, L. M. V. Survey of Brazilian tomato products for alternariol, alternariol monomethyl ether, tenuazonic acid, and cyclopiazonic acid. Food Additives and Contaminants, v. 18, n. 7, p. 630-634, 2001.

MUHAMMAD, S.; SHEHU, K.; AMUSA, N. A. Survey of the market diseases and aflatoxin contamination of tomato (Lycopersicon esculentum MILL) fruits in Sokoto, northwestern Nigeria. Nutrition and Food Science, v. 34, n. 2, p. 72-76, 2004.

MUTTI, P.; DELLAPINA, G.; SPOTTI, E. Produzione, stabilità, diffusione, screening di aflatossine in derivati del pomodoro. Industria Conserve, v. 67, n. 1, p. 39-41, 1992.

NORTHOLT, M. D.; VANEGMOND, H. P.; PAULSCH, W. E. Differences between Aspergillus-flavus strains in growth and aflatoxin-b1 production in relation to water activity and temperature. Journal of Food Protection, v. 40, n. 11, p. 778-781, 1977.

OBETA, J. A. N.; UGWUANYI, J. O. Heat-resistant fungi in Nigerian heat-processed fruit juices. International Journal of Food Science and Technology, v. 30, n. 5, p. 587-590, 1995.

OLADIRAN, A. O.; IWU, L. N. Studies on the fungi associated with tomato fruit rots and effects of environment on storage. Mycopathologia, v. 121, n. 3, p. 157-161, 1993.

PEARSON, R. C.; HALL, D. H. Factors affecting the occurrence and severity of blackmold of ripe tomato fruit caused by Alternaria alternata. Phytopathology, v. 65, n. 12, p. 1359, 1975.

PETERSON, S. W. et al. Aspergillus bombycis, a new aflatoxigenic species and genetic variation in its sibling species, A-nomius. Mycologia, v. 93, n. 4, p. 689-703, 2001.

PITT, J. I.; MISCAMBLE, B. F. Water relations of Aspergillus flavus and closely related species. Journal of Food Protection, v. 58, n. 1 , p. 86-90, 1995.

RAMAKRISHNA, N.; LACEY, J.; SMITH, J. E. Aspergillus flavus colonization and aflatoxin B-1 formation in barley grain during interaction with other fungi. Mycopathologia, v. 136, n. 1, p. 53-63, 1996.

SCOTT, P. M.; KANHERE, S. R. Liquid chromatographic of tenuazonic acids in tomato paste. Journal of the Association of Official Analytical Chemists, v. 63, n. 3, p. 612-621, 1980.

SOARES, L. M. V.; RODRIGUEZ-AMAYA, D. B. Survey of aflatoxins, ochratoxin A, zearalenone, and sterigmatocystin in some Brazilian foods, utilizing a multi-toxin thin layer chromatographic method. Journal of the Association of Official Analytical Chemists, v. 72, n. 1, p. 22-26, 1989.

STACK, M. E. et al. Liquid-chromatographic determination of tenuazonic acid and alternariol methyl ether in tomatoes and tomato products. Journal of the Association of Official Analytical Chemists, v. 68, n. 4, p. 640-642, 1985.

TRUCKSESS, M. W.; STOLOFF, L.; MISLIVEC, P. B. Effect of temperature, water activity and other toxigenic mold species on growth of aspergillus-flavus and aflatoxin production on corn, pinto beans and soybeans. Journal of Food Protection, v. 51, n. 5, p. 361-363, 1988 . 